\title{
Effect of maternal body condition on placental and fetal growth and the insulin-like growth factor axis in Dorset ewes
}

\author{
J. C. Osgerby, T. S. Gadd and D. C. Wathes* \\ Reproduction and Development Group, The Royal Veterinary College, Hawkshead Lane, North Mymms, \\ Hatfield, Hertfordshire AL9 TTA, UK
}

This study investigated the effects of maternal body condition on fetal growth. Fetal and placental parameters from Dorset ewes of body condition score 2.0 (lean, $n=5)$, 3.5 (moderate, $n=7$ ) and 5.0 (fat, $n=4$ ) at mating were studied on day 65 of gestation. The fetal weight and fetal weight:crown-rump length ratio were greater in fat ewes than in ewes of moderate condition. The raised total and mean placentome weight in fat ewes compared with ewes of moderate condition may have contributed to their increased fetal growth. However, the fetal crown-rump length was not affected. With in situ hybridization, insulinlike growth factor II (IGF-II) mRNA and insulin-like growth factor binding protein 2 (IGFBP-2), -3 and -6 were all detected in the placentome capsule; IGF-II mRNA was also found in the mesoderm of the fetal villi and IGFBP-3 and IGFBP- 6 were present in the caruncular stroma of the maternal villi. Ewes of moderate condition, which had the smallest placentae, had the greatest placental expression of IGF-II, IGFBP-2 and IGFBP-3. In the intercotyledonary endometrium, IGFBP-3, IGFBP-5 and uterine milk protein (UTMP) mRNA were all expressed in the glandular epithelium. IGFBP-3 and IGFBP-5 absorbance values were lowest in the lean ewes, whereas UTMP values were highest. Maternal insulin concentrations were greater in fat ewes, whereas plasma glucose and IGF-I concentrations in the fetal compartment were lowest in fat ewes. Therefore, in obese ewes, fetal and placental growth is increased in mid-gestation in association with higher maternal insulin concentrations and lower expression of IGFBPs in the maternal placentomes. Placental and fetal development in lean ewes may be promoted by reduced IGFBP expression in the placentomes and enhanced UTMP production by the endometrial glands. The ewes of moderate condition had the smallest fetuses and placentae coupled with the highest placental expression of IGF-II and IGFBPs.

\section{Introduction}

Although the fetal genome undoubtedly influences fetal size, the intrauterine environment and in particular the fetal nutrient supply is also a major determinant of fetal growth (Walton and Hammond, 1938; CarrHill et al., 1987; Gluckman et al., 1990; Harding and Johnston, 1995). Various consequences of fetal undernutrition present at birth, with low-birth weight lambs, for example, having an increased incidence of death from hypothermia, infection and starvation (Alexander, 1974). Complications also arise in later life: human epidemiological studies reveal an increased predisposition to infertility (Ibnaez et al., 2000), cardiovascular disease and non-insulin-dependent diabetes in adults born with a low-birth weight (Barker, 1995). In sheep, unsuitable maternal nutrition during pregnancy can compromise future wool (for review, see Black, 1983; Kelly et al., 1996) and carcass quality (for review, see Bell, 1992) and reproductive performance (Gunn et al., 1995; for review,

*Correspondence

Email: dcwathes@rvc.ac.uk see Rhind et al., 2001). The term 'fetal programming' is used to describe such permanent alterations in fetal development (for review, see Barker and Clark, 1997; McMillen et al., 2001).

Inappropriate substrate delivery to the fetus may compromise fetal growth by modifying the nutritionally sensitive glucose-insulin-insulin-like growth factor I (IGF-I) axis within the fetal compartment (Fowden, 1995). Although the fetus develops its own endogenous reserves (Fowden, 1997), it depends primarily on the mother for nutritional support. Factors that regulate fetal substrate delivery are thus important determinants of fetal growth. Nutrients provided directly from the maternal compartment, via the placenta, are derived either from products of digestion after ingestion or as mobilized components of the maternal body reserves (McCrabb et al., 1992a). Despite the impact of maternal diet on fetal growth having been addressed (Holst et al., 1992; McCrabb et al., 1992a; Heasman et al., 1999; Osgerby et al., 2002), the effects of maternal body condition are less well understood.

The placenta mediates the exchange of substrate and waste products between the dam and fetus, as well as 
moderating the composition of specific substrate (Chung et al., 1998). The ewe has a cotyledonary placenta, with fetomaternal exchange taking place at 88-100 discrete sites known as placentomes (Latshaw, 1987). The number of placentomes is fixed by day 56 of gestation (Wallace, 1948), whereas placental proliferation peaks between days 50 and 60, and the placenta attains a maximum weight by day 80 (term 150; Ehrhardt and Bell, 1995). Inappropriate maternal nutrition in early-mid-pregnancy can disrupt placental development, with the condition of the mother at mating reportedly affecting this interaction (McCrabb et al., 1992b).

Gene-deletion studies in mice indicate that the IGF system, a nutritionally sensitive group of proteins, has a fundamental role in placental as well as fetal development (Baker et al., 1993; for reviews, see Wathes et al., 1998; Han and Carter, 2000). IGF-I and IGF-II act via the type 1 IGF receptor (IGF-1R) to mediate cellular proliferation, differentiation and metabolism (Jones and Clemmons, 1995). IGF-2R acts as a degradative pathway, removing excess IGF-II from the circulation (Braulke, 1999). IGF binding proteins (IGFBPs), IGFBP-1-6, modulate the biological activities of the IGFs (Ferry et al., 1999).

Endocrine factors within the maternal circulation may also influence fetal substrate availability, regulating nutrient partitioning between the maternal, placental and fetal compartments (Wallace et al., 1997, 2001). Two closely related glucose transporters, GLUT1 and GLUT3, transport glucose across the placenta by facilitated diffusion (Bell et al., 1999). Glucose regulates the expression of these transporters in a time- and concentration-dependent fashion (Das et al., 1998, 2000). Insulin promotes lipogenesis within the maternal compartment, mediating glucose and amino acid uptake by the adipose and muscle tissue (Vernon et al., 1981; McNeill et al., 1997). IGF-I, in contrast, influences the placental transfer of glucose and amino acids (Kniss et al., 1994; Liu et al., 1994).

In addition to placentally derived substrate, factors of uterine origin also support fetal development. The uterine milk proteins (UTMPs) are the most prevalent proteins in the pregnant ovine uterine luminal fluid, and are considered to offer nutritional support to the fetus, in addition to providing other binding, carrier and immunomodulatory actions within the uterine space (Moffatt et al., 1987; Skopets and Hansen, 1993; Hansen, 1998; McFarlane et al., 1999).

This study aimed to determine the effects of maternal body condition on fetal growth and to elucidate the mechanisms involved. The effects of maternal body condition on factors regulating fetal substrate delivery were investigated, including placenta and maternal plasma concentrations of glucose, insulin and IGF-I. The effects of maternal body condition on placental growth were determined by investigating the uterine IGF and IGFBP mRNA axis using in situ hybridization on day
65 of gestation, during the highly proliferative phase of placental growth. The effect of body condition on UTMP expression was also studied.

\section{Materials and Methods}

\section{Animals}

All procedures were performed under the UK Animals (Scientific Procedures) Act 1986 and took place within the normal seasonal breeding cycle of the Dorset ewe (Ovis aries). Mature, multiparous Dorset ewes $(n=19)$ were fed to yield three groups of differing body condition scores. These scores were reached 12 weeks before mating to prevent a flushing effect before mating. Body condition scoring assesses the muscle and fat cover of an animal. In sheep, the condition is determined by careful palpation of the spinous and transverse processes in the loin area, immediately behind the last rib and above the kidney. This region provides an accurate indication of the present condition of the ewe, as condition is last to be laid down here but first to be lost (Henderson, 1990). The condition is interpreted on a scale of 1.0-5.0 where 1.0 is emaciated and 5.0 obese (based on the criteria of the Meat and Livestock Commission, 1988). In this study, ewes were 2.0 (lean, group L; $n=5$ ), 3.5 (moderate, group $\mathrm{M} ; n=8$ ) or 5.0 (fat, group F; $n=6$ ). Maternal body condition and weight were assessed weekly throughout the study.

All animals were individually housed 9 weeks before mating to allow time for acclimatization. Ewes were housed on wheat-straw bedding under conditions of natural light and ambient temperature with free access to water. Ewes were fed a complete diet of pelleted sheep nuts providing $100 \%$ of their daily maintenance requirements to sustain condition (based on the criteria of the Meat and Livestock Commission, 1988). The complete diet was fed in two equal rations at 08:00 and 16:00 h daily and supplied 10.8 MJ metabolizable energy and $150 \mathrm{~g}$ crude protein per $\mathrm{kg}$ dry matter. The rations were reviewed weekly and altered according to changes in maternal body weight and the stage of gestation.

Oestrus was synchronized by withdrawing progestagen impregnated sponges (60 mg medoxyprogesterone acetate, Veramix; Upjohn Ltd, Crawley) 12 days after insertion. At sponge withdrawal, ewes received an injection of a prostaglandin $\mathrm{F}_{2 \alpha}\left(\mathrm{PGF}_{2 \alpha}\right)$ analogue, Estrumate $(0.5 \mathrm{ml}$ i.m.; Schering Plough Animal Health, Uxbridge) before being presented to two raddled Texel rams $48 \mathrm{~h}$ later. The ewes were checked for raddle marks (an indicator of mating) four times a day and day 0 of gestation was taken as the first date at which an obvious raddle mark was first observed. Pregnancy was confirmed by measuring plasma progesterone concentrations on day 16 of gestation using an enzymeimmunoassay kit (Ridgeway Science Ltd, Alvington). 


\section{Measurements}

On day 65 of gestation the gravid uterus was removed post mortem through a midline incision at a consistent point along the length of the cervix and weighed. Fetal blood samples were collected by cardiac puncture immediately before intra-cardiac administration of sodium pentabarbitone to the fetus. The blood was placed on ice for no more than 20 min before being centrifuged at $1500 \mathrm{~g}$ for $15 \mathrm{~min}$ at $4^{\circ} \mathrm{C}$ and then stored at $-20^{\circ} \mathrm{C}$ until analysis. The fetus was blotted dry, weighed and sexed, and the crown-rump length was measured. From the body of the uterus four placentomes and six pieces of intercotyledonary endometrium (with fetal membranes attached) were dissected. All tissue samples were wrapped in aluminium foil, rapidly frozen in liquid nitrogen-tempered isopentane and stored at $-80^{\circ} \mathrm{C}$ until required for sectioning. The remaining placentomes were dissected from the uterine wall, counted and individually weighed.

\section{Blood sampling and assays}

Maternal blood samples were collected weekly by jugular venepuncture from 3 weeks of gestation onwards (after confirmation of pregnancy), $5 \mathrm{~h}$ after the morning feed. These and the fetal blood samples were analysed for systemic insulin, glucose and IGF-I. Maternal plasma IGF-I was analysed by radioimmunoassay after ethanol-acetone-acetic acid extraction according to the method of Enright et al. (1989) using recombinant human IGF-I (rhIGF-I; Bachem Ltd, Saffron Waldon) as standard, iodinated rhIGF-I (iodogen method) as tracer, and antibody raised against rhIGF-I (Biogenesis Ltd, Poole). The detection limit was $8.6 \mathrm{ng} \mathrm{ml}^{-1}$ and the inter- and intra-assay coefficients of variation (CVs) were $8.3 \%$ and $3.1 \%$, respectively. Fetal plasma IGF-I concentrations were measured by a two-site immunoenzymatic assay kit (DRG Diagnostics, Immunodiagnostic Systems Ltd, Tyne and Wear). The detection limit was $6.0 \mathrm{ng} \mathrm{ml}^{-1}$ and the inter- and intra-assay coefficients of variation were $1.18 \%$ and $2.5 \%$, respectively. Plasma insulin was measured by ELISA (DRG Diagnostics, Immunodiagnostic Systems Ltd, Tyne and Wear). The detection limit was $0.1 \mathrm{ng} \mathrm{ml}^{-1}$ and the inter- and intra-assay CVs were $7.1 \%$ and $3.2 \%$, respectively. Maternal plasma glucose was measured by an enzymatic colorimetric method according to the method of Werner et al. (1971), using a glucose reagent from Roche Diagnostics (Lewes). Colour development was monitored at $420 \mathrm{~nm}$. The detection limit was $1.5 \mathrm{mmol} \mathrm{I}^{-1}$ and the inter- and intra-assay CVs were $2.7 \%$ and $2.2 \%$, respectively. Fetal plasma glucose was below the limit of detection of this technique and was therefore measured using an automated glucose analyser (Bayer Opera, Business Group Diagnostics, Tarrington, NY).

\section{In situ hybridization}

Oligonucleotide probes. All probes used were single-stranded oligonucleotides (Babraham Institute, Cambridge). Sense probes were always included as negative controls as any signal produced on applying this probe could be regarded as non-specific. IGF-II, IGFBP-2, IGFBP-3 and IGFBP-6 mRNA were investigated in the placentomes. IGFBP-3, IGFBP-5 and UTMP mRNA were studied in the intercotyledonary tissue (the areas of endometrium between the placentomes). These probes were chosen for each region based on previous studies on the localization of the placental IGF system during ovine pregnancy (Reynolds et al., 1997; Gadd et al., $2000 a, b)$. All probes used in the study are described (Table 1).

Localization of mRNA by in situ hybridization. This procedure was performed as described by Reynolds et al. (1997). All chemicals were purchased from Sigma Chemical Co. (Poole) or BDH (Poole), unless otherwise stated. In summary, frozen placentome and intercotyledonary tissue sections were cut (10 $\mu \mathrm{m}$ thick) and thaw-mounted onto $1 \mathrm{mg} \mathrm{ml}^{-1}$ poly-L-lysine $\left(M_{r}>300000\right)$-coated glass slides. Sections were fixed in $4 \%(\mathrm{w} / \mathrm{v})$ paraformaldehyde in $0.01 \mathrm{~mol} \mathrm{PBS} \mathrm{I}^{-1}$ at $\mathrm{pH} 7.0$ for $5 \mathrm{~min}$ at room temperature $\left(20^{\circ} \mathrm{C}\right)$, before three washes in $0.01 \mathrm{~mol}$ PBS $\mathrm{I}^{-1}$ and sequential dehydration in $70 \%$ and $95 \%$ ethanol.

The oligonucleotide (5ng) was labelled with $\left[{ }^{35} \mathrm{~S}\right]$ dATP (Amersham International, Aylesbury) at the 3 '-end using deoxynucleotidyl transferase (Pharmacia Biotech, St Albans) at $34^{\circ} \mathrm{C}$ for $60 \mathrm{~min}$. The labelled probe was subsequently diluted to a final concentration of 1:100000 c.p.m. $\mathrm{ml}^{-1}$ in hybridization buffer and $100 \mu \mathrm{l}$ was added to each section. The sections were incubated in a humidified box overnight at $42.5^{\circ} \mathrm{C}$. After incubation, slides were washed in $1 \times \mathrm{SSC} 0.2 \%(\mathrm{w} / \mathrm{v}) \mathrm{so}-$ dium thiosulphate pentahydrate solution at room temperature for $30 \mathrm{~min}$, then at a higher stringency in $1 \times \mathrm{SSC}$ $0.2 \%(\mathrm{w} / \mathrm{v})$ sodium thiosulphate pentahydrate solution for $60 \mathrm{~min}$ at $57.5^{\circ} \mathrm{C}$. Sections were finally rinsed in $1 \times$ SSC, $0.1 \times$ SSC, $70 \%$ ethanol, and 95\% ethanol, for $1 \mathrm{~min}$ each. Slides were then air-dried for at least $2 \mathrm{~h}$ and exposed to $\beta$-max hyperfilm (Amersham International) for the time indicated (Table 1). Uterine samples shown to be positive for each of the probes (Reynolds et al., 1997; Wathes et al., 1998) were included in each experiment as a positive control.

\section{Photographic emulsions}

Slides previously exposed to X-ray film were coated with a photographic emulsion (LM1; Amersham International) according to the manufacturer's instructions and stored at $4{ }^{\circ} \mathrm{C}$ for the time indicated (Table 1). Slides were then developed in $20 \%$ phenisol (v/v), fixed in $1.9 \mathrm{~mol}$ sodium thiosulphate-pentahydrate $\mathrm{I}^{-1}$, 
Table 1. The sequence of the antisense probes and exposure times for in situ hybridization, $\mathrm{X}$-ray films and emulsions

\begin{tabular}{|c|c|c|c|}
\hline \multirow[b]{2}{*}{ Probe } & \multirow[b]{2}{*}{ Antisense sequence } & \multicolumn{2}{|c|}{ Exposure time (days) } \\
\hline & & X-ray film & Emulsion \\
\hline IGF-II & $\begin{array}{l}\text { 554-598 of ovine IGF-II gene (O'Mahoney and Adams, 1989) } \\
\text { 5'-AAC-TGG-AGG-GTG-TCC-ACC-AGC-TCC-CCG-CCG-CAC-AGA-GTC- } \\
\text { TCG-CTG-3' }\end{array}$ & 21 & 28 \\
\hline IGFBP-2 & $\begin{array}{l}\text { 452-496 of ovine IGFBP-2 gene (Delhanty and Han, 1992) } \\
\text { 5'-CAG-AGT-GCT-CCT-CGC-CAT-TGT-CTG-CAA-CCT-GCT-CGG-GGC- } \\
\text { TGG-CGC-3' }\end{array}$ & 30 & 37 \\
\hline IGFBP-3 & $\begin{array}{l}\text { 546-578 of bovine IGFBP-3 gene (Spratt et al., 1991) } \\
\text { 5'-AGC-CTG-GTT-CTC-TGT-GCT-CCC-CAT-GCT-GTG-GTC-3' }\end{array}$ & 30 & 37 \\
\hline IGFBP-5 & $\begin{array}{l}\text { 291-335 of bovine IGFBP-5 gene (Moser et al., 1992) } \\
\text { 5'-TCG-GAG-ATG-CGG-GTG-TGC-TTG-GGC-CGG-AAG-ATC-TTG-GGC- } \\
\text { GAG-TAG-3' }\end{array}$ & 21 & 28 \\
\hline IGFBP-6 & $\begin{array}{l}\text { 292-336 of bovine IGFBP-6 gene (Moser et al., 1992) } \\
\text { 5'-CCG-CTT-CCG-GTA-GAA-GCC-CCT-ATG-GTC-ACA-ATT-AGG-CAC- } \\
\text { GTA-GAG-3' }\end{array}$ & 30 & 37 \\
\hline UTMP & $\begin{array}{l}\text { 1210-1254 of ovine UTMP gene (Ing and Roberts, 1989) } \\
\text { 5'-GTT-GAA-CTT-AAC-AAC-CAC-CGG-GAC-CTC-CTT-CGT-GTT-CGC- } \\
\text { GGG-GAC-3' }\end{array}$ & 10 & 17 \\
\hline
\end{tabular}

IGF-II: insulin-like growth factor II; IGFBP: insulin-like growth factor binding protein; UTMP: uterine milk protein.

and counterstained with haematoxylin and eosin for microscopic confirmation of the cellular localization of the radioactive signal.

\section{Absorbance measurements}

An image analysis system (Seescan plc, Cambridge) was used to quantify the radioactive signal as arbitrary absorbance units using a linear grey scale of 0.0-2.1 (Reynolds et al., 1997). A blank section of film was placed under the image analyser lens and measured to determine a background reading of the autoradiograph under analysis. Measurements were made of the antisense and sense images obtained from four sections per sample. At least six readings per section were taken, giving a minimum of 24 readings per region per sample, for each region where localization had been confirmed. The sense values were subtracted from the antisense values to produce a mean value of specific hybridization for a particular region for that sample. The detection limit was taken as an arbitrary absorbance unit greater than 0.01 . The CVs for duplicate measurements of the pairs of slides were as follows: IGF-II, $6.5 \%$; IGFBP-2, $4.2 \%$; IGFBP-3, $11.0 \%$; IGFBP-5, 4.9\%; IGFBP-6, $1.8 \%$; and UTMP, $7.7 \%$. All samples for each probe were processed in the same batch to avoid any possible interbatch variation.

\section{Statistical analysis}

All values are given as mean \pm SEM. Statistical analyses were performed using Statistical Package for the Social Sciences (SPSS) version 9.0. A one-way ANOVA was used to test the effects of body condition on: (i) fetal parameters; (ii) placental parameters; and (iii) IGF or UTMP mRNA expression in a given uterine region. Fisher's LSD tests were used to determine which parameters differed between groups. If the data were non-homogeneous, including after log-transformation, a Kruskal-Wallis non-parametric one-way ANOVA was performed. The data were pooled if no changes were detected. Maternal insulin, glucose and IGF-I concentrations were analysed using a repeated measures design using the MIXED procedures of SAS (version 6.12 ). Correlation analysis was performed to analyse the relationship between variables.

\section{Results}

\section{Maternal parameters}

Of the 19 ewes mated, 16 had singleton pregnancies and three had twins (two in group F and one in group $\mathrm{M})$. The data presented in this study concern only ewes that had singleton pregnancies (F: $n=4 ; \mathrm{M}: n=7$ and $\mathrm{L}: n=5)$, to avoid any nutritional effects of the number of fetuses. The weights of the ewes were significantly different at mating (F: $75.8 \pm 2.32^{\mathrm{a}} \mathrm{kg}$ versus M: $63.6 \pm$ $1.58^{\mathrm{b}} \mathrm{kg}$ versus $\mathrm{L}: 57.4 \pm 2.01^{\mathrm{c}} \mathrm{kg} ; \mathrm{a}>\mathrm{b}>\mathrm{c}, P<0.03$ ). All ewes maintained their specified body condition score throughout the study.

\section{Placental and fetal data}

The mean placentome weight, fetal weight and fetal weight:crown-rump length ratio were significantly 
Table 2. The effect of maternal body condition on uterine, placental and fetal parameters in ewes on day 65 of gestation

\begin{tabular}{lcrr}
\hline & \multicolumn{3}{c}{ Body condition score } \\
\cline { 2 - 4 } & 5.0 (fat, $n=4)$ & 3.5 (moderate, $n=7$ ) & $2.0($ lean, $n=5)$ \\
\hline Mean placentome weight $(\mathrm{g})$ & $8.2 \pm 1.17^{\mathrm{a}}$ & $5.8 \pm 0.62^{\mathrm{b}}$ & $6.2 \pm 0.30^{\mathrm{a}, \mathrm{b}}$ \\
Total placentome number & $86 \pm 4.0$ & $89 \pm 6.2$ & $92 \pm 2.9$ \\
Fetal weight (g) & $110 \pm 2.82^{\mathrm{a}}$ & $97.3 \pm 2.42^{\mathrm{b}}$ & $103 \pm 4.89^{\mathrm{a}, \mathrm{b}}$ \\
Crown-rump length (cm) & $15.8 \pm 0.22$ & $15.6 \pm 0.14$ & $15.6 \pm 0.17$ \\
Fetal weight:crown-rump length $\left(\mathrm{g} \mathrm{cm}^{-1}\right)$ & $6.9 \pm 0.18^{\mathrm{a}}$ & $5.2 \pm 0.14^{\mathrm{b}}$ & $6.6 \pm 0.34^{\mathrm{a}, \mathrm{b}}$ \\
Total placentome weight (g) & $703 \pm 94.7^{\mathrm{c}}$ & $515 \pm 54.8^{\mathrm{d}}$ & $576 \pm 46.6^{\mathrm{c}, \mathrm{d}}$ \\
Total uterine weight $(\mathrm{g})$ & $1900 \pm 154^{\mathrm{e}}$ & $1449 \pm 144^{\mathrm{f}}$ & $1539 \pm 178^{\mathrm{e}, \mathrm{f}}$ \\
\hline
\end{tabular}

Values are the mean \pm SEM.

Within rows a $>$ b $P<0.05 ; \mathrm{c}>\mathrm{d}, P<0.06$; e $>\mathrm{f}, P<0.07$.

greater in fat ewes than in ewes of moderate condition $(P<0.05$; Table 2). A similar trend was observed for the total placentome weight $(P<0.06)$ and total uterine weight $(P<0.07$; Table 2$)$. All parameters measured in the lean ewes were intermediate between the other two groups (Table 2). When all the groups were considered together, the fetal weight tended to be positively correlated with the total $(r=0.469, P<0.07, n=16)$ and mean $(r=0.469, P<0.07, n=16)$ placentome weight, but there was no significant relationship between fetal weight and the weight of the mother at mating. Factors unaltered by body condition were ( $n=16$ in each case): total number of placentomes $(89.7 \pm 2.92)$, fetal crownrump length $(15.7 \pm 0.10 \mathrm{~cm})$, placenta weight:fetal weight ratio $(5.67 \pm 0.35)$ and ponderal index $(0.03 \pm$ $0.0007 \mathrm{~g} \mathrm{~cm}^{-3}$ ).

\section{In situ hybridization data}

IGF-II mRNA was localized in the placentome capsule, the fetal mesoderm in both the fetal villi of the placentome and in the intercaruncular region, and within the glands and luminal epithelium of the intercotyledonary endometrium (Fig. 1). IGF-II expression was highest in the ewes of moderate condition in the fetal mesoderm, placentome capsule and luminal epithelium (Fig. 2), although there was no effect of body condition score on expression in the glands $(0.11 \pm 0.01$ absorbance units, $n=15)$.

IGFBP-2, IGFBP-3 and IGFBP-6 were all expressed in the placentome capsule and IGFBP-3 and IGFBP-6 mRNA were also present in the stroma of the maternal villi (Fig. 3). Within the capsule the absorbance values of these IGFBPs were consistently highest in the ewes of moderate condition, although only that of IGFBP-2 achieved statistical significance (Fig. 4). Expression of IGFBP-3 (0.03 \pm 0.007 absorbance units, $n=16)$ and IGFBP-6 (0.13 \pm 0.01 absorbance units, $n=15)$ in the maternal villi was unaffected by body condition.

IGFBP-3 and IGFBP-5 were both expressed in both the luminal and glandular epithelium in the intercoty- ledonary endometrium (Fig. 5). There was no effect of body condition score on expression in the luminal epithelium (IGFBP-3: $0.11 \pm 0.01$ absorbance units; IGFBP-5: $0.90 \pm 0.03$ absorbance units, $n=16$ ), but in the glands, IGFBP-3 and IGFBP-5 values showed a progressive decrease from the fat ewes, through the ewes of moderate condition, to the lean ewes (Fig. 6).

UTMP mRNA was localized in the luminal epithelium and at significantly higher concentrations in the endometrial glands (Fig. 5). Expression in the glands was greatest in the lean ewes (Fig. 6). Evidence from the photographic emulsions revealed that the UTMP mRNA was not uniformly distributed over the luminal epithelium but was restricted to areas adjacent to the mouths of glands. Concentrations in the luminal epithelium were unaffected by body condition $(0.08 \pm 0.04$ absorbance units, $n=15$ ).

\section{Maternal plasma insulin, glucose and IGF-I}

Plasma insulin concentrations altered significantly with body condition, with fat ewes having greater insulin concentrations than lean ewes and ewes of moderate condition between day 20 and day 48 of gestation (Fig. 7a; $P<0.04$ ). Maternal insulin was positively correlated with the weight of the ewe at mating $(r=0.603$, $P<0.05, n=15)$. In contrast, maternal insulin was negatively correlated with UTMP expression in the endometrial glands ( $r=0.509, P<0.05, n=16)$. Body condition had no significant overall effect on plasma glucose (Fig. 7b) or IGF-I concentrations (Fig. 7c).

\section{Fetal plasma glucose, IGF-I and insulin}

Fetal plasma glucose concentrations were highest in ewes of moderate condition (Table 3). Because maternal glucose concentrations were similar in all groups, the fetal:maternal glucose ratio followed a similar (although non-significant) trend with values highest in fetuses in the fat ewes and lowest in those from ewes of moderate condition. Fetal insulin concentrations also followed this 

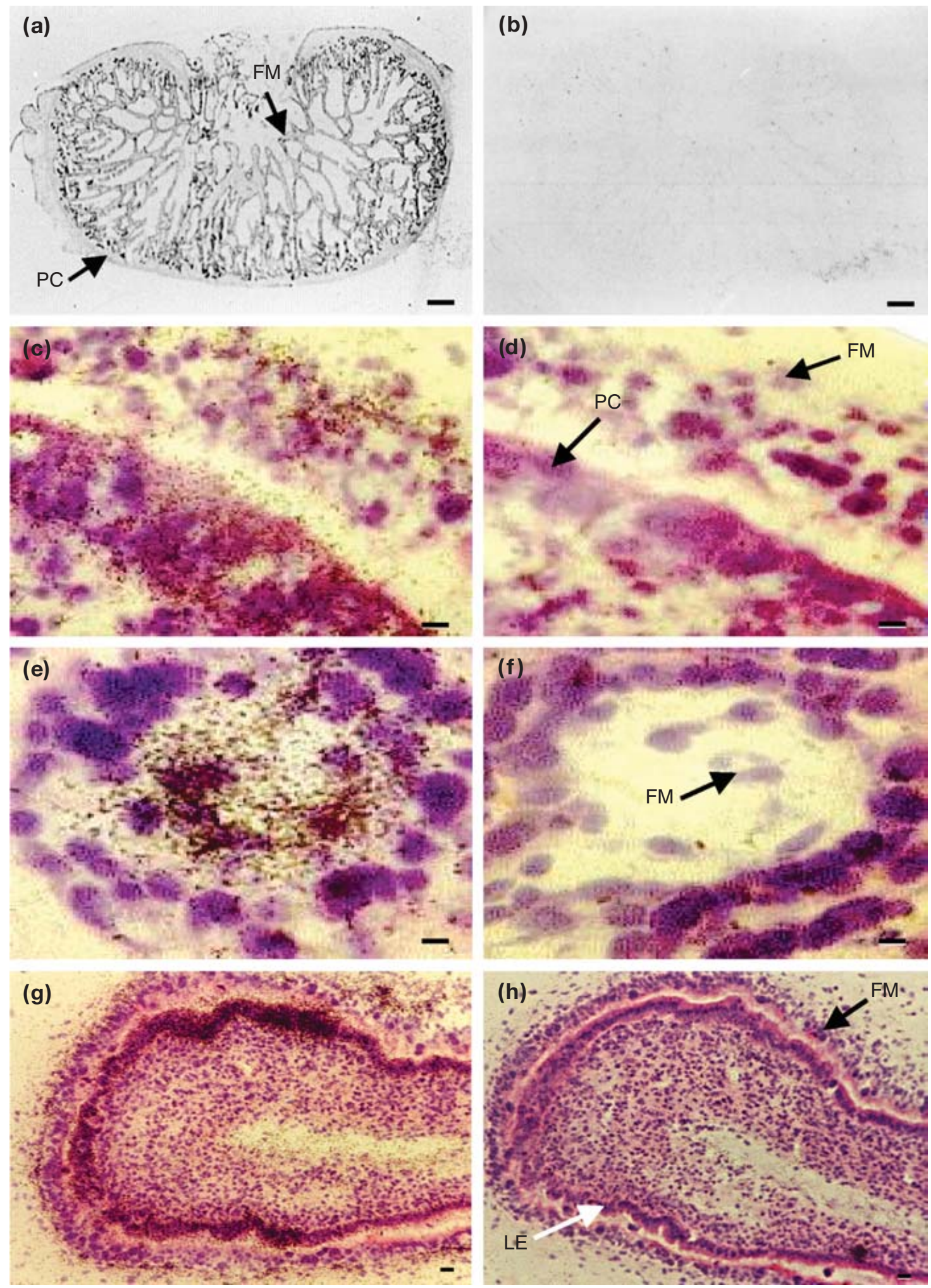

Fig. 1. Localization of insulin-like growth factor II (IGF-II) mRNA in the ovine placentome (a-f) and intercotyledonary tissue $(\mathrm{g}, \mathrm{h})$ on day 65 of gestation. Sections were treated with antisense $(\mathrm{a}, \mathrm{c}, \mathrm{e}, \mathrm{g})$ or sense (control; b, d,f,h) oligonucleotide probes. (a) and (b) are autoradiographs; (c-h) are sections coated with photographic emulsion and counterstained with haematoxylin and eosin. In the placentome, IGF-II mRNA is expressed in the placentome capsule (PC; c,d) and mesoderm of the fetal villi (FM; e,f). In the intercotyledonary tissue, IGF-II mRNA is localized in the luminal epithelium (LE) and fetal mesoderm (FM) (g,h). Scale bars represent (a,b) 2 mm and (c-h) $200 \mu \mathrm{m}$. 
same pattern and were negatively correlated with the mean placentome weight $(P<0.05)$. Fetal plasma IGF-I concentrations were lowest in the fat ewes (Table 3). Fetal IGF-I was negatively correlated with the weight of the ewe at mating $(r=0.49, P<0.05, n=16)$ and the placentome:fetal weight ratio $(r=0.49, P<0.05$, $n=16)$.

\section{Discussion}

This study investigated the effects of maternal body condition at mating on placental and fetal growth. Previous research in sheep has demonstrated the importance of acquiring an optimum body condition score before mating, as body condition, ovulation rate and subsequent lambing percentages are inter-related (Henderson, 1990). Nutrient availability around mating may influence earlyembryo survival, possibly via effects on oocyte quality (Snijders et al., 2000) or progesterone production (Abecia et al., 1997). Sufficient body reserves are also required for utilization during pregnancy and in lactation, when feeding is commonly of poorer quality and more expensive (Henderson, 1990). In lowland ewes, such as the Dorset breed, optimum lambing percentages are achieved at body condition score 3.5, with underfeeding and overfeeding depressing ovulation rates (Henderson, 1990; MAFF, 1996). In the present study, maternal body condition also altered fetal growth, with the ewes of moderate condition having the smallest fetuses in midgestation. This result indicates that different mechanisms may have occurred to promote fetal growth in early gestation in the fat and lean ewes, such that fetal weights in the two extreme groups were similar.

The fat ewes were characterized by higher placental and fetal weights, and there was a trend $(P<0.07)$ for these two parameters to be correlated. A similar positive relationship between fetal and placental weights has been documented in previous studies (sheep: Kelly, 1992; Gadd et al., 2000a; humans: Schubring et al., 1997). The body mass index, a measure of maternal fatness (weight/height ${ }^{2}$ ), was positively correlated with placental and fetal weight in women (Perry et al., 1995), and Kinare et al. (2000) also reported a relationship between the pre-pregnancy weight of the mother and the placental volume in mid-gestation. In contrast, Greenwood et al. (2000) found a negative relationship between maternal fatness in early gestation with placental and fetal weight at birth in the ewe and in the present experiment there was no correlation between weight of the ewe at mating and fetal weight at day 65. Therefore, it is clear that the relationships between body condition and placental and fetal development are not straightforward and are also almost certainly influenced by diet and breed effects, which vary between experiments. Furthermore, the relationship between fetal and placental weight may change during the
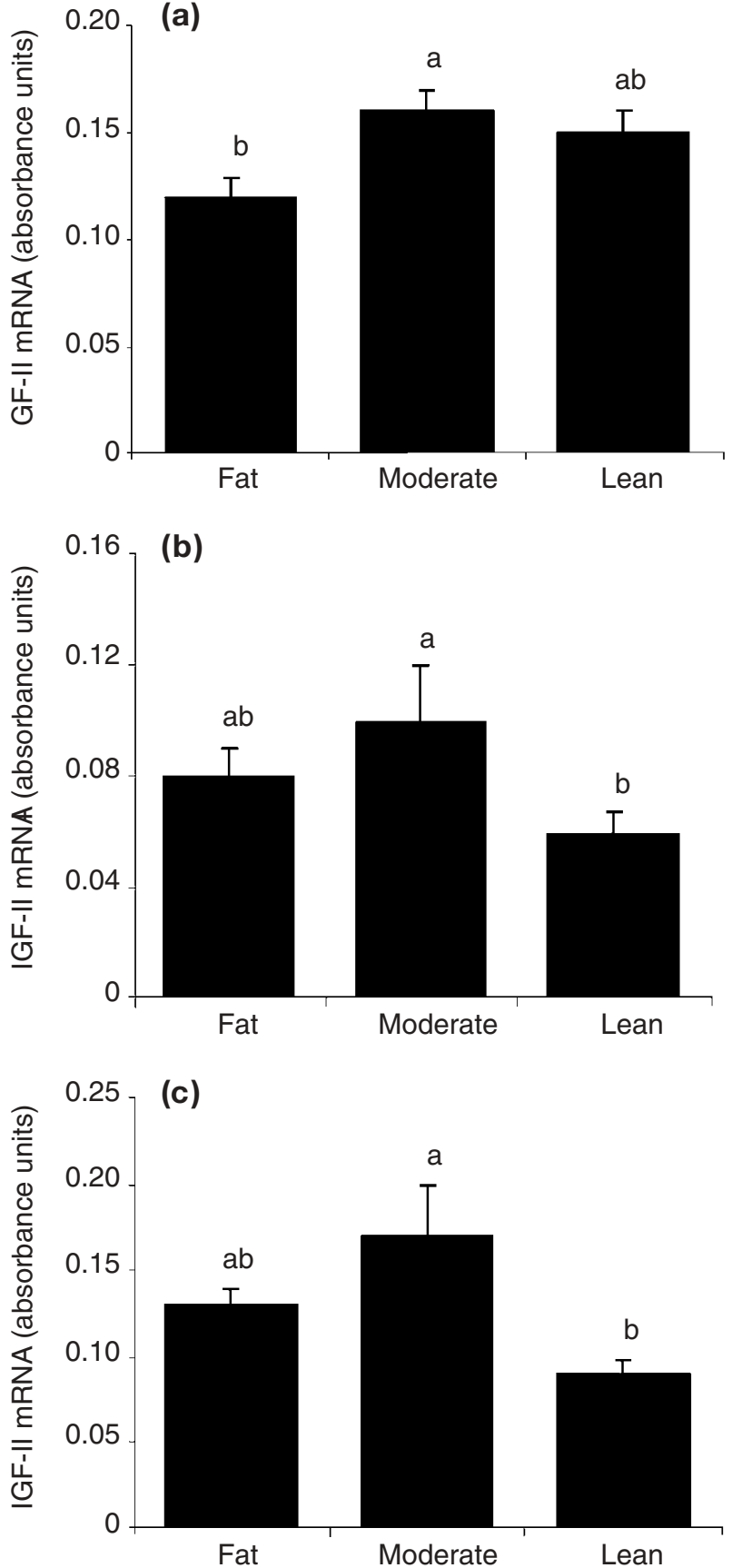

Fig. 2. Insulin-like growth factor II (IGF-II) mRNA expression measured as arbitrary absorbance units in (a) mesoderm of the fetal villi, (b) placentome capsule and (c) luminal epithelium in the intercotyledonary endometrium in ewes of body condition score 5.0 (fat, $n=4$ ), 3.5 (moderate, $n=7$ ) or 2.0 (lean, $n=5$ ). Expression was consistently highest in the ewes of moderate condition $(a>b, P<0.05)$. Values are the mean \pm SEM.

course of the pregnancy (Heasman et al.,1998; Osgerby et al., 2002).

In addition to absolute weight, the fetal programming hypothesis has drawn attention to the importance of fetal proportions as a guide to health in later life (Barker and 

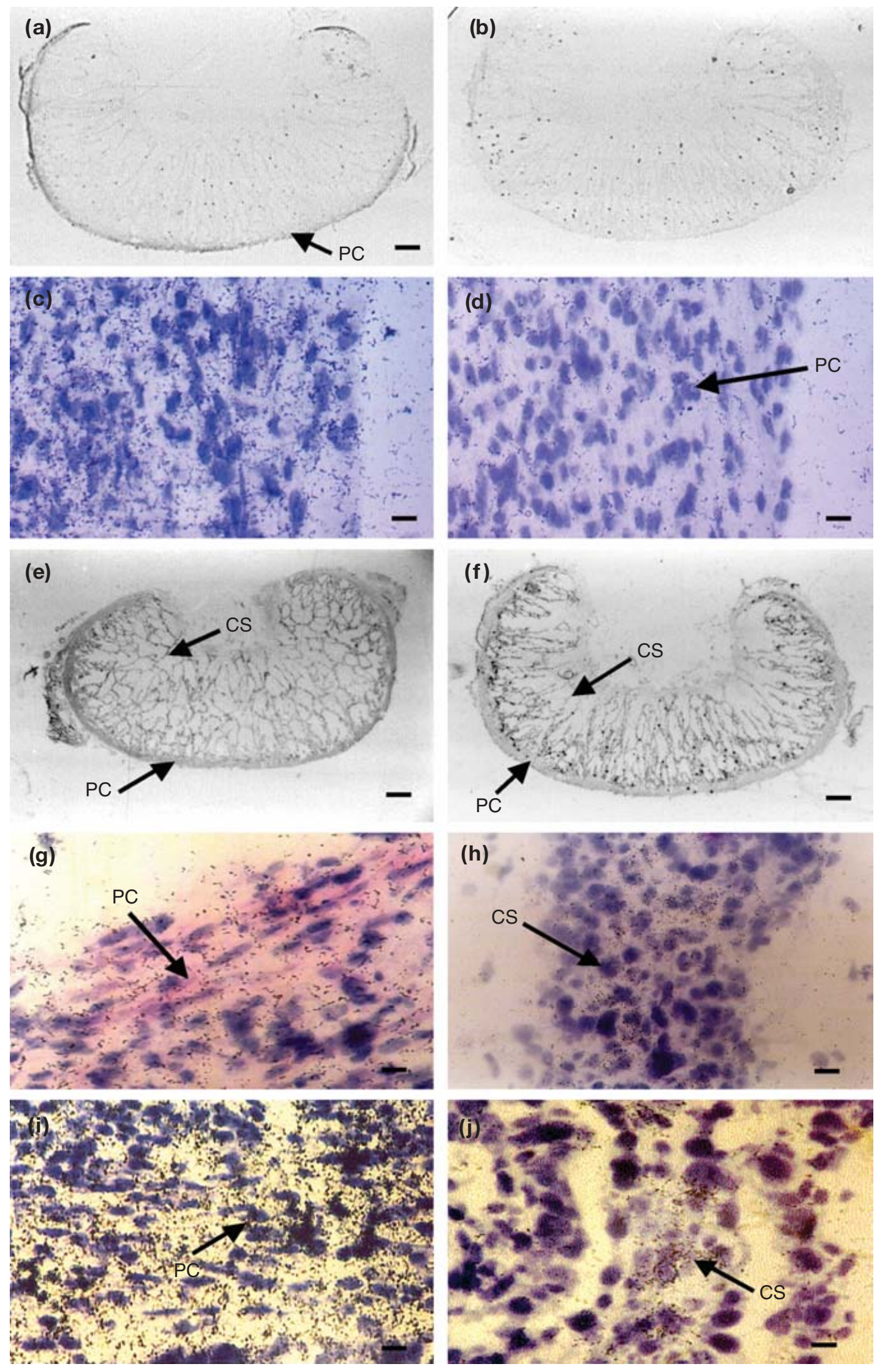

Fig. 3. See legend on facing page. 
Clarke, 1997). In the fat ewes compared with the ewes of moderate condition, the fetal crown-rump length was unchanged despite the heavier fetal weight, resulting in an increased fetal weight:crown-rump length ratio. Maternal fatness thus altered fetal growth asymmetrically, appearing to promote soft tissue development, whereas skeletal growth remained unchanged. Maternal obesity has been related to an increased incidence of congenital heart defects in humans (Watkins and Botto, 2001). Maternal body condition may therefore influence fetal development such that peri-natal and post-natal health can be compromised.

The increased placental and fetal weights in the obese ewes were associated with increased maternal insulin concentrations, although maternal IGF-I and glucose concentrations were not significantly altered by maternal body condition. Previous studies in sheep fed to achieve a zero energy balance found that insulin, IGF-I and glucose concentrations were all higher in obese animals than in lean animals (McCann et al., 1997). The increase in insulin was attributable to an exaggerated glucose-induced response rather than to decreased insulin removal (McCann et al., 1989). Although the insulin concentrations were higher early in gestation in the present study, the insulin concentrations in all body-condition score groups converged from day 55 of gestation onwards. At this time, placental and fetal demands for glucose are increasing. This may remove glucose from the maternal circulation in an insulinindependent fashion unrelated to the extent of obesity. In a similar way, adolescent ewes with a high intake have exhibited increased concentrations of insulin in comparison with groups of moderate intake (Wallace et al., 1999). However, contrary to the present findings, the high concentrations of insulin promoted maternal tissue deposition at the expense of placental growth; both maternal weight and placental weight were increased in the present study. This finding indicates that the implications of increased maternal insulin may differ between growing and mature ewes.

Contrary to findings in the maternal compartment, plasma glucose, insulin and IGF-I concentrations were lowest in the fetal compartment of fat ewes. As maternal insulin and IGF-I do not cross the placenta in physiologically relevant amounts (Brown and Thorburn, 1989), concentration on the fetal side is regulated independently. Fetal plasma IGF-I was negatively correlated with maternal weight and the placental:fetal weight ratio. As glucose provides energy and carbon for growth,
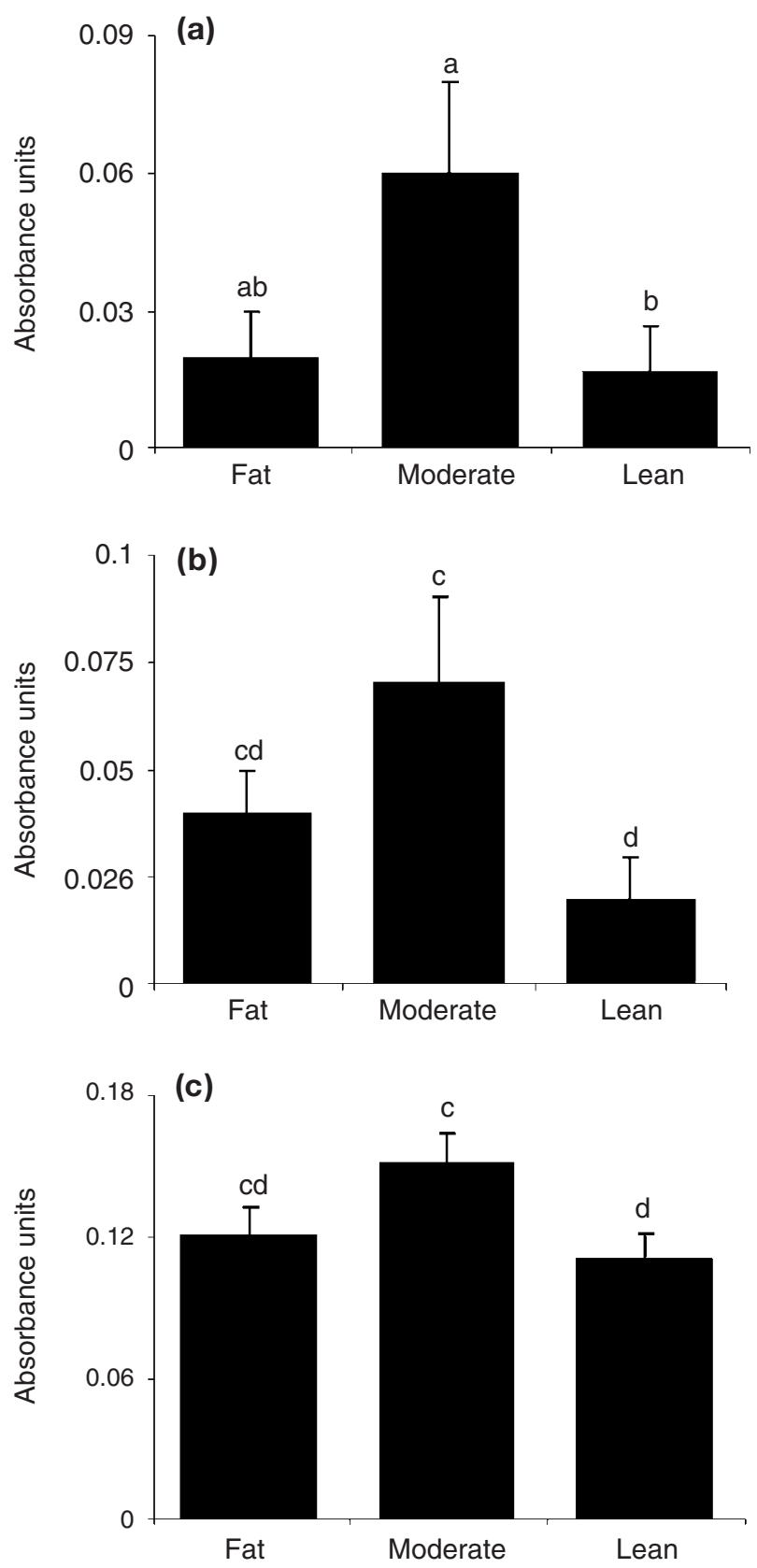

Fig. 4. Insulin-like growth factor binding protein (IGFBP) mRNA expression measured in arbitrary absorbance units in the placentome capsule. There were three groups of ewes of body condition score 5.0 (fat, $n=4$ ), 3.5 (moderate, $n=7$ ) or 2.0 (lean, $n=5$ ). Expression of all three IGFBPs tended to be higher in the ewes of moderate condition ( $\mathrm{a}>\mathrm{b}, P<0.05$; $\mathrm{c}>\mathrm{d}, P<0.08)$. Values are the mean \pm SEM.

Fig. 3. The localization of insulin-like growth factor binding protein 2 (IGFBP-2; a-d), IGFBP-3 (e,g,h) and IGFBP-6 (f,i,j) mRNA in the ovine placentome. $(\mathrm{a}, \mathrm{b}, \mathrm{e}, \mathrm{f})$ are autoradiographs; $(\mathrm{c}, \mathrm{d}, \mathrm{g}-\mathrm{j})$ are sections coated with photographic emulsion and counterstained with haematoxylin and eosin. Sections were hybridized with either $(\mathrm{a}, \mathrm{c}, \mathrm{e}-\mathrm{j})$ antisense or $(\mathrm{b}, \mathrm{d})$ sense (control) oligonucleotide probes. (a,c) IGFBP-2, (e,g) IGFBP-3 and (f,i) IGFBP-6 mRNA were localized in the placentome capsule (PC) with (h) IGFBP-3 and (j) IGFBP-6 also being expressed in the caruncular stroma (CS) of the maternal villi. Scale bars represent $(a, b, e, f) 2 m m$ and $(c, d, g-j) 200 \mu m$. 


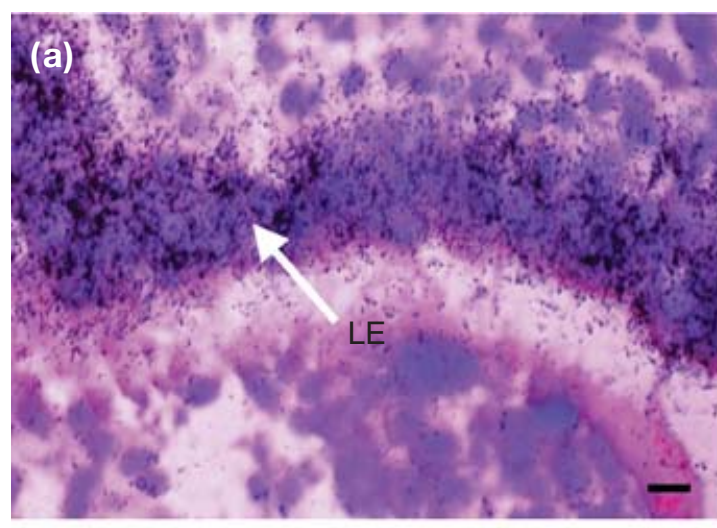

(c)
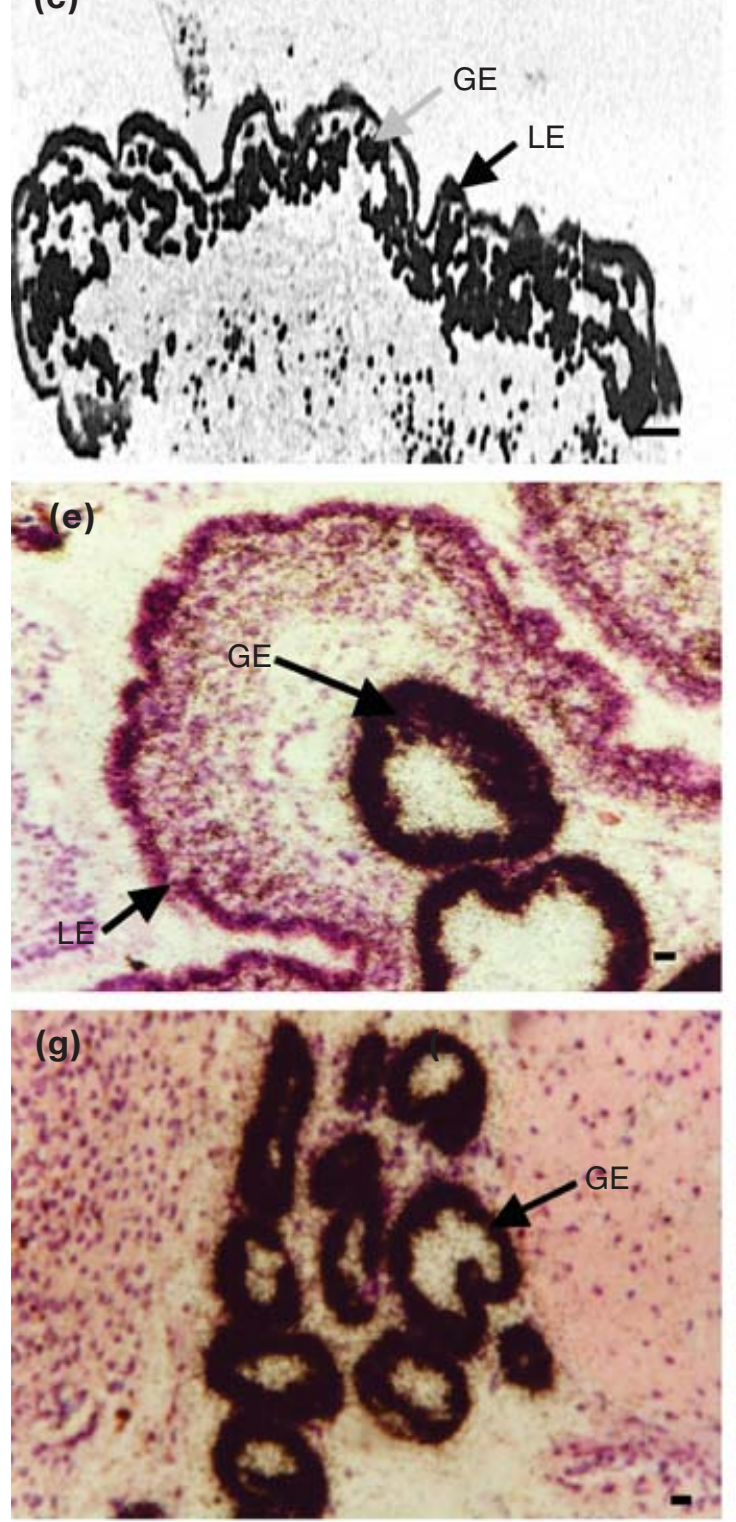

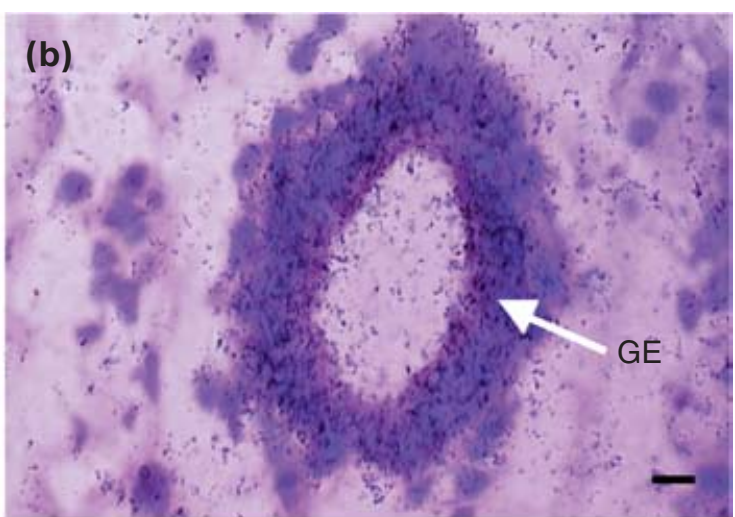

(d)

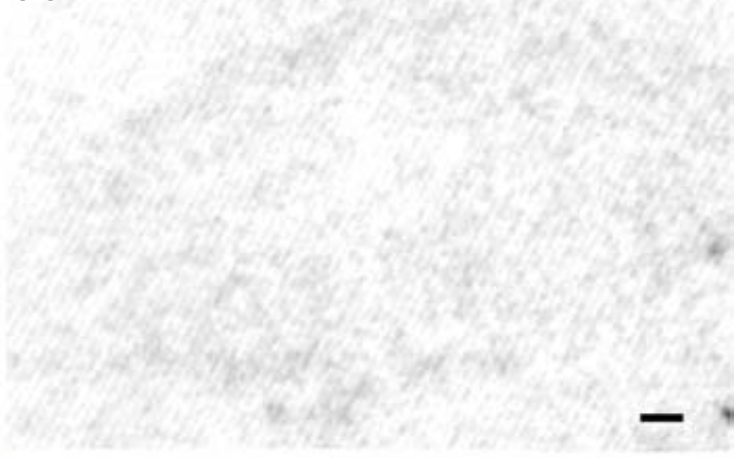

(f)
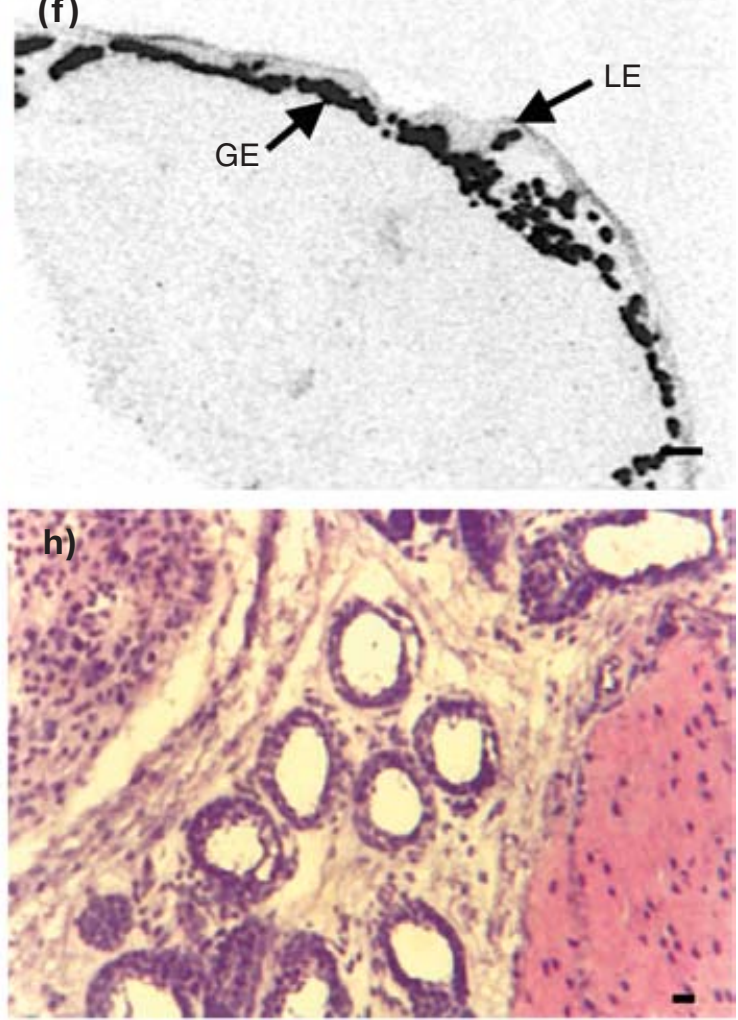

Fig. 5. Localization of insulin-like growth factor binding protein 3 (IGFBP-3; a,b), IGFBP-5 (c-e) and uterine milk protein (UTMP; $\mathrm{f}-\mathrm{h}$ ) mRNA in the luminal epithelium (LE) and glandular epithelium (GE) of the ovine intercotyledonary endometrium on day 65 of gestation. UTMP expression was not uniform in the luminal epithelium but was confined to areas adjacent to the mouths of the glands. There was also intermittent expression of IGFBP-5 in the area underlying 

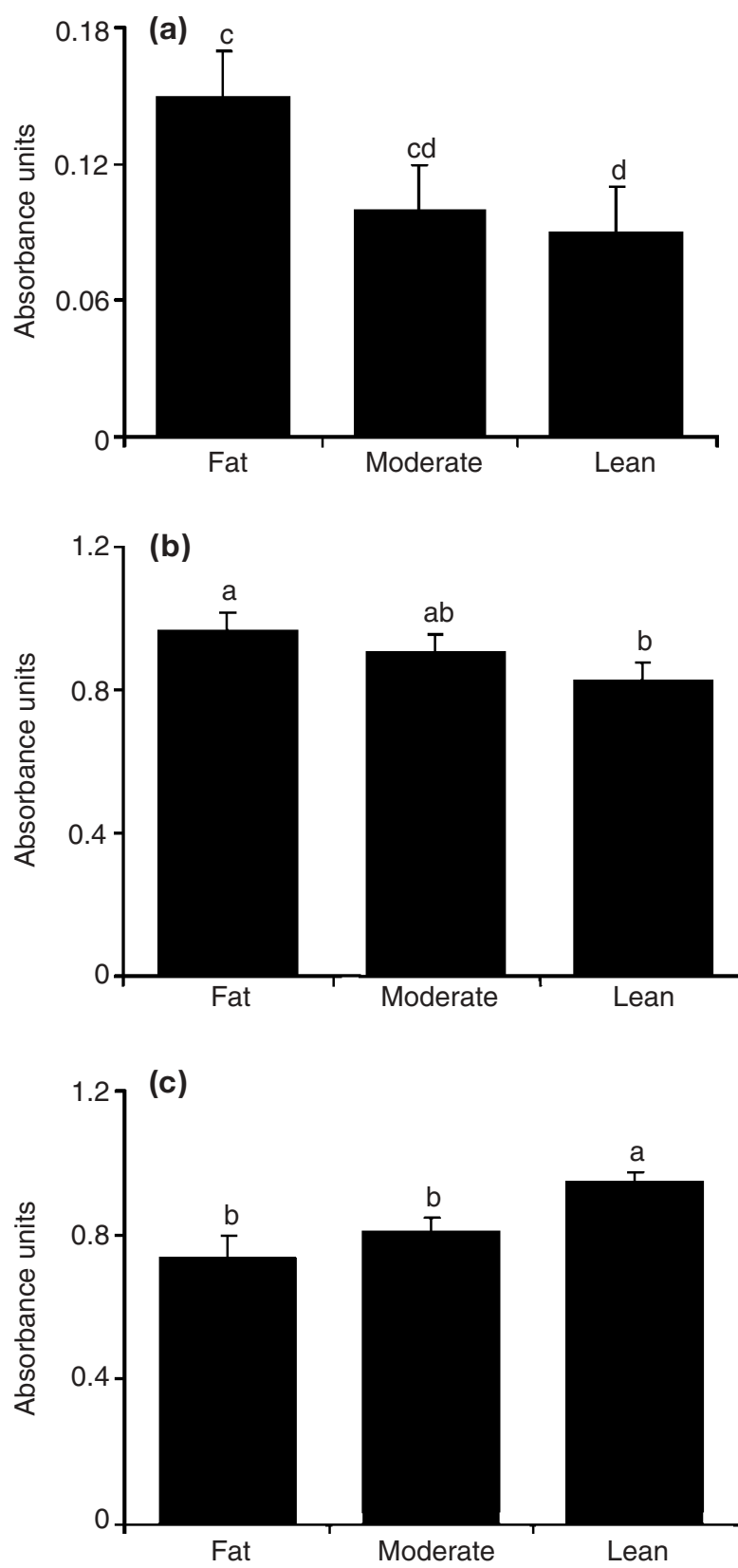

Fig. 6. (a) Insulin-like growth factor binding protein 3 (IGFBP-3), (b) IGFBP-5 and (c) uterine milk protein (UTMP) mRNA expression measured in arbitrary absorbance units in the glandular epithelium of the intercotyledonary endometrium. There were three groups of ewes of body condition score 5.0 (fat, $n=4$ ), 3.5 (moderate, $n=7$ ) or 2.0 (lean, $n=5$ ). IGFBP expression was maximal in the fat ewes ( $\mathrm{a}>\mathrm{b}, P<0.05 ; \mathrm{c}>\mathrm{d}, P<0.08$ ), whereas UTMP expression was highest in the lean ewes $(a>b, P<0.05)$. Values are the mean \pm SEM.
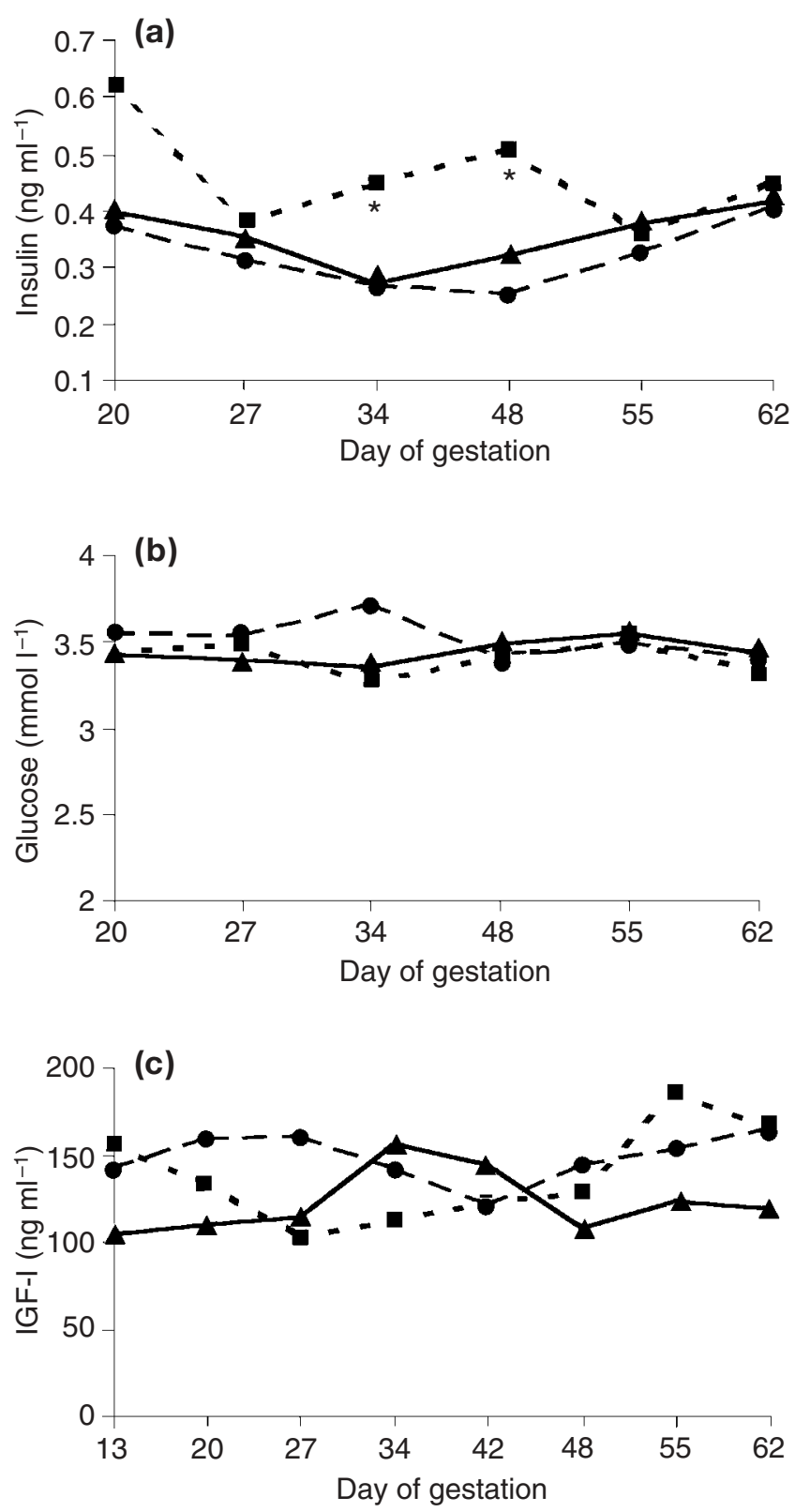

Fig. 7. Maternal metabolite profiles for plasma (a) insulin, (b) glucose and (c) insulin-like growth factor I (IGF-I) in ewes of fat ( $\mathbf{\square}$, $n=4)$, moderate $(\boldsymbol{\Lambda}, n=7)$ and lean $(\bullet, n=5)$ body condition. Values are the mean. The overall SEM for each group is as follows: insulin ( $\mathrm{ng} \mathrm{m} \mathrm{m}^{-1}$ ): fat \pm 0.05 , moderate \pm 0.02 , lean \pm 0.03 ; glucose $\left(\mathrm{mmol} \mathrm{l}^{-1}\right)$ : fat \pm 0.05 , moderate \pm 0.03 , lean \pm 0.05 ; IGF-I $\left(\mathrm{ng} \mathrm{ml}^{-1}\right)$ : fat \pm 14.2 , moderate \pm 7.01 , lean \pm 6.4 . Fat ewes had greater insulin concentrations than lean ewes and ewes of moderate condition $(* P<0.04)$, but glucose and IGF-I values were not significantly different between groups. are autoradiographs. Scale bars represent $(c, d, f) 2 \mathrm{~mm}$ and $(\mathrm{a}, \mathrm{b}, \mathrm{e}, \mathrm{g}, \mathrm{h}) 200 \mu \mathrm{m}$. 
Table 3. The effect of maternal body condition on plasma glucose, insulin and insulin-like growth factor I (IGF-I) in the ovine fetus on day 65 of gestation

\begin{tabular}{lcrr}
\hline & \multicolumn{2}{c}{ Body condition score } \\
\cline { 2 - 4 } & 5.0 (fat, $n=4)$ & 3.5 (moderate, $n=7)$ & $2.0($ lean, $n=5)$ \\
\hline Fetal plasma glucose $\left(\mathrm{mmol} \mathrm{I}^{-1}\right)$ & $1.1 \pm 0.16^{\mathrm{b}}$ & $2.1 \pm 0.18^{\mathrm{a}}$ & $1.5 \pm 0.11^{\mathrm{b}}$ \\
Fetal:maternal glucose ratio & $2.7 \pm 0.70$ & $1.7 \pm 0.15$ & $2.3 \pm 0.14$ \\
Fetal plasma insulin $\left(\mathrm{ng} \mathrm{ml}^{-1}\right)$ & $0.10 \pm 0.02$ & $0.17 \pm 0.03$ & $0.11 \pm 0.02$ \\
Fetal plasma IGF-I $\left(\mathrm{ng} \mathrm{ml}^{-1}\right)$ & $19.4 \pm 1.28^{\mathrm{b}}$ & $24.1 \pm 0.92^{\mathrm{a}}$ & $23.3 \pm 1.93^{\mathrm{a}, \mathrm{b}}$ \\
\hline
\end{tabular}

Values are the mean \pm SEM.

Within rows $\mathrm{a}>\mathrm{b}, P<0.05$.

insulin promotes tissue accretion, and IGF-I exerts metabolic, mitogenic and differentiative activites, the factors responsible for promoting the fetal growth observed in fat ewes remain to be elucidated. Although the differences failed to reach statistical significance, the group of fat ewes in the present study had the highest fetal:maternal glucose ratio, whereas this was lowest in the lean ewes. This gradient is one of the key factors regulating glucose transfer across the placenta, which would be expected to increase with the higher ratio (Hay et al., 1990).

A major aim of the present study was to investigate potential mechanisms whereby placental growth may be regulated. Gene-deletion studies in mice have emphasized the significance of the IGF axis to placental and fetal growth. Mice lacking the IGF-II gene exhibit placental hypoplasia and produce progeny that are $60 \%$ of their normal birth weight (DeChiara et al., 1990; Baker et al., 1993). In a similar way, deletion from the mouse IGF-II gene of a transcript specifically expressed in the labyrinthine trophoblast resulted in decreased placental growth from day 12 of gestation, which was followed by fetal growth restriction from day 16 onwards (Constancia et al., 2002). IGF-II can potentiate growth by at least four inter-related actions (Gardner et al., 1999). IGF-II is expressed in ewes in the placentome capsule and at higher concentrations in the mesoderm of the fetal villi (Reynolds et al., 1997; Osgerby et al., 1999a). However, in the present study, ewes of moderate condition developed the smallest placentas despite expressing the greatest placental IGF-II mRNA concentrations. Previous work in sheep has not determined any positive relationships between concentrations of placental IGFII expression and placental growth in adolescent (Gadd et al., 2000a) or adult (Osgerby et al., 2003) ewes on different diets. Circulating IGF-II concentrations in nonpregnant ewes are no different in lean and obese animals (McCann et al., 1997). These data strongly indicate that although IGF-II is clearly a major growth factor in the placenta, the nutritional control of ovine placental growth is not regulated via altered IGF-II expression.

The present study provides further evidence that the regulation is mediated via altered IGFBP expression.
The IGFBPs can modulate IGF action by intercepting receptor interaction and ligand transduction (Wetterau et al., 1999). Maternal body condition altered placental IGFBP expression in the present study, and ewes of moderate condition tended to express the greatest concentrations of IGFBP-2, IGFBP-3 and IGFBP-6 in the placentome capsule. This combined increase in IGFBP concentrations may have contributed to the low placental weights observed in this group by inhibiting IGF-II action. These results are consistent with two previous studies in which expression of IGFBP-3 in the maternal placental villi (Osgerby et al., 2003) and IGFBP-2 expression in the placentome capsule (Gadd et al., 2000a) were higher in sheep with smaller placentae.

In lean ewes, conversely, the low IGFBP expression found in the placentomes in the present study may have enabled these animals to acquire a similar placental weight to the ewes of moderate condition. In addition to the placenta, the fetus acquires support from the UTMPs secreted from the endometrial glands (Stewart et al., 2000). Glandular UTMP expression was negatively related to both maternal weight and maternal plasma insulin concentrations. IGFBP-3 $(P<0.04)$ and IGFBP-5 $(P<0.08)$ expression in the endometrial glands was positively correlated with maternal weight, with lean ewes expressing lower concentrations than fat ewes. Therefore, the lean ewes were able to compensate for their poor condition by altering IGFBP expression in both the placentomes and glands to promote placental growth and the glandular supply of nutrients. Compensatory placental growth has previously been reported in Welsh Mountain ewes of low-body condition at mating (Osgerby et al., 1999b), in ewes with maternal feed restriction in early pregnancy (Heasman et al., 1998), and in cows in poor body condition (Rasby et al., 1990). However, it is possible that the lean ewes would have been unable to sustain this compensatory mechanism in late gestation when nutrient demands increase.

This study has focused mainly on the IGF system as a possible mediator of placental and fetal growth but other possible modulators should also be considered. For example, Thomas et al. (2001) used 
immunocytochemistry to detect leptin protein at the maternal and fetal interface of the ovine placenta and proposed that leptin may mediate nutrient partitioning to the fetus via interaction with placental leptin receptors. Leptin synthesis is nutritionally sensitive (Levy and Stevens, 2001), with circulating concentrations varying according to the maternal body condition, dietary intake and plasma insulin concentrations (Thomas et al., 2001). Thus, the effects of body condition on leptin function and fetal growth warrant further investigation.

In summary, maternal body condition altered fetal growth asymmetrically in mid-gestation in the present study. Fetal weight and the fetal weight:crown-rump length ratio were modified, whereas skeletal growth remained unchanged. This finding indicates that aspects of fetal development are sensitive to maternal body condition, potentially producing significant implications on health in post-natal life. These changes in fetal development may be attributed to alterations in placental weight, uterine IGF and UTMP expression and systemic insulin associated with differing maternal body conditions.

The authors wish to thank the Wellcome Trust and the Biotechnology and Biological Sciences Research Council (BBSRC) for their financial support. The authors would also like to thank D. Manners and J. Thompson for their care of the animals, and B. Wilsmore for preparation of the photographs.

\section{References}

Abecia JA, Lozano JM, Forcada F and Zarazanga L (1997) Effect of level of dietary energy and protein on embryo survival and progesterone production on day 8 in pregnancy in Rasa Aragonesa ewes Animal Reproduction Science $\mathbf{4 8}$ 209-218

Alexander G (1974) Birth weight of lambs: influences and consequences. In Size at Birth pp 215-239 Eds K Elliot and J Knight. Associated Scientific Publishers, Amsterdam

Baker J, Lui J-P, Robertson EJ and Efstratiadis A (1993) Role of insulin-like growth factors in embryonic and post-natal growth Cell 75 73-82

Barker DJP (1995) Fetal origins of coronary heart disease British Medical Journal 311 171-174

Barker DJP and Clark PM (1997) Fetal undernutrition and disease in later life Reviews of Reproduction 2 105-112

Bell AW (1992) Foetal growth and its influence on postnatal growth and development. In The Control of Fat and Lean Deposition pp 111-127 Eds KN Boormann, PJ Buttery and DB Lindsay. Butterworth-Heinemann Ltd, Oxford

Bell AW, Hay WW and Ehrhardt RA (1999) Placental transport of nutrients and its implications for fetal growth Journal of Reproduction and Fertility Supplement 54 401-410

Black JL (1983) Growth and development of lambs. In Sheep Production pp 21-58 Ed. W Haresign. Butterworths, London

Braulke T (1999) Type-2 IGF receptor: a multi-ligand binding protein Hormone Metabolism and Research 31 242-246

Browne CA and Thorburn GD (1989) Endocrine control of fetal growth Biology of the Neonate 55 331-346

Carr-Hill R, Campbell DM, Hall MH and Meredith A (1987) Is birthweight determined genetically? British Medical Journal 295 687-689

Chung M, Teng C, Timmerman M, Meschia G and Battaglia FC (1998) Production and utilization of amino acids by ovine placenta in vivo. American Journal of Physiology - Endocrinology and Metabolism $\mathbf{2 7 4}$ E13-E22
Constancia $M$, Hemberger $M$, Hughes J, Dean W, Ferguson-Smith A, Fundele R, Stewart F, Kelsey G, Fowden A, Sibley C and Reik W (2002) Placental specific IGF-II is a major modulator of placental and fetal growth Nature 417 945-948

Das UG, Sadiq HF, Soares MJ, Hay WW and Devaskar SU (1998) Time dependent physiological regulation of rodent and ovine placental glucose transporter (GLUT-1) protein American Journal of Physiology Regulatory, Integrative and Comparative Physiology 274 R339-R347

Das UG, Ehrhardt RA, Hay WW and Devaskar SU (2000) Time-dependent physiological regulation of ovine placental GLUT-3 glucose transporter protein American Journal of Physiology - Regulatory, Integrative and Comparative Physiology 279 R2252-R2261

DeChiara TM, Efstratiadis A and Robertson EJ (1990) A growth-deficiency phenotype in heterozygous mice carrying an insulin-like growth factor II gene disrupted by targeting Nature 345 78-80

Delhanty PJD and Han VKM (1992) The characterization and expression of ovine insulin-like growth factor binding protein-2 Journal of Molecular Endocrinology 9 31-38

Ehrhardt RA and Bell AW (1995) Growth and metabolism of the ovine placenta during mid-gestation Placenta 16 727-741

Enright WJ, Chapin LT, Moseley WM, Zinn SA, Kamdar MB, Krabill LF and Tucker HA (1989) Effects of infusions of various doses of bovine growth hormone-releasing factor on blood hormones and metabolites in lactating Holstein cows Journal of Endocrinology 122 671-679

Ferry RJ, Katz LEL, Grimberg A, Cohen P and Weinzimer SA (1999) Cellular actions of insulin-like growth factor binding proteins Hormone Metabolic Research 31 192-202

Fowden AL (1995) Endocrine regulation of fetal growth Reproduction, Fertility and Development 7 351-363

Fowden AL (1997) Comparative aspects of fetal carbohydrate metabolism Equine Veterinary Journal 24 19-25

Gadd TS, Aitken RP, Wallace JM and Wathes DC (2000a) Effect of a high maternal dietary intake during mid-gestation on components of the utero-placental insulin-like growth factor (IGF) system in adolescent sheep with retarded placental development Journal of Reproduction and Fertility 118 407-416

Gadd TS, Osgerby JC and Wathes DC (2000b) Regulation and localisation of insulin-like growth factor binding protein-5 gene expression in the uterus and placenta of the cyclic and early pregnant ewe Biology of Reproduction 62 1415-1421

Gardner RL, Squire S, Zaina A, Hills S and Graham CF (1999) Insulinlike growth factor-2 regulation of conceptus composition: effects of the trophectoderm and inner cell mass genotypes in the mouse Biology of Reproduction 60 190-195

Gluckman PD, Breier BH, Oliver M, Harding J and Bassett N (1990) Fetal growth in late gestation - a constrained pattern of growth Acta Paediatrica Scandinavia Supplementum 367 105-110

Greenwood PL, Slepetis RM and Bell AW (2000) Influences on fetal and placental weights during mid to late gestation in prolific ewes well nourished throughout pregnancy Reproduction, Fertility and Development 12 149-156

Gunn RG, Sim DA and Hunter EA (1995) Effects of nutrition in utero and in early-life on the subsequent lifetime reproductive-performance of Scottish Blackface ewes in two management-systems Animal Science $60223-230$

Han VKM and Carter AM (2000) Spatial and temporal patterns of expression of messenger RNA for insulin like growth factors and their binding proteins in the placenta of man and laboratory animals Placenta $\mathbf{2 1}$ 289-305

Hansen PJ (1998) Regulation of uterine immune function by progesterone - lessons from the sheep Journal of Reproductive Immunology $\mathbf{4 0}$ 63-79

Harding JE and Johnston BM (1995) Nutrition and fetal growth Reproduction, Fertility and Development 7 539-547

Hay WW, Molina RA, DiGiacomo JE and Meschia G (1990) Model of placental glucose consumption and glucose transfer American Journal of Physiology 258 R569-R577

Heasman L, Clarke L, Firth K, Stephenson TJ and Symonds ME (1998) Influence of restricted maternal nutrition in early to mid-gestation on 
placental and fetal development at term in sheep Pediatric Research $\mathbf{4 4}$ 1-6

Heasman L, Clarke L, Stephenson TJ and Symonds ME (1999) The influence of maternal nutrient restriction in early to mid-pregnancy on placental and fetal development in sheep Proceedings of the Nutrition Society 58 283-288

Henderson DC (1990) The Veterinary Book for Sheep Farmers. Farming Press Books, Ipswich

Holst PJ, Allan CJ and Gilmour AR (1992) Effects of a restricted diet during mid-pregnancy of ewes on uterine and fetal growth and lamb birth weight Australian Journal of Agricultural Research 43 315324

Ibnaez L, Potau N, Enrique G and de Zegher F (2000) Reduced uterine and ovarian size in adolescent girls born small for gestational age Pediatric Research 48 575-577

Ing NH and Roberts RM (1989) The major progesterone-modulated proteins secreted into the sheep uterus are members of the serpin superfamily of serine protease inhibitors Journal of Biological Chemistry 2643372 3379

Jones JI and Clemmons DR (1995) Insulin-like growth factors and their binding proteins: biological actions Endocrine Reviews 16 3-34

Kelly RW (1992) Nutrition and placental development Proceedings Nutrition Society of Australia 17 203-211

Kelly RW, MacLeod I, Hynd P and Greeff J (1996) Nutrition during fetal life alters annual wool production and quality in young Merino sheep Australian Journal of Experimental Agriculture 36 259267

Kinare AS, Natekar AS, Chinchwadkar MC, Yajnik CS, Coyaji KJ, Fall CH and Howe DT (2000) Low mid-pregnancy placental volume in rural Indian women: a cause for low birth weight? American Journal of Obstetrics and Gynaecology 182 443-448

Kniss DA, Shubert PJ, Zimmerman PD, Landon MB and Gabbe SG (1994) Insulin-like growth factors. Their regulation of glucose and amino acid transport in placental trophoblasts isolated from first-trimester chorionic villi Journal of Reproductive Medicine 39 249-256

Latshaw WK (1987) Extraembryonic membranes and placentation. In Veterinary Developmental Anatomy - A Clinically Oriented Approach pp 49-74. Blackwell Scientific Publications, Oxford

Levy JR and Stevens W (2001) The effects of insulin, glucose and pyruvate on the kinetics of leptin secretion Endocrinology $1423558-3562$

Liu L, Harding JE, Evans PC and Gluckman PD (1994) Maternal insulin-like growth factor-I infusion alters feto-placental carbohydrate and protein metabolism in pregnant sheep Endocrinology 135 895-900

McCann JP, Bergmann EN and Reimers TJ (1989) Effects of obesity and ovarian steroids on insulin secretion and removal in sheep American Journal of Physiology 256 E119-E128

McCann JP, Loo SC, Aalseth DL and Abribat T (1997) Differential effects of GH stimulation on fasting and prandial metabolism and plasma IGFs and IGF binding proteins in lean and obese sheep Journal of Endocrinology 154 329-346

McCrabb GJ, Hosking BJ and Egan AR (1992a) Changes in the maternal body and feto-placental growth following various lengths of feed restriction during mid-pregnancy in sheep Australian Journal of Agricultural Research 43 1429-1440

McCrabb GJ, Egan AR and Hosking BJ (1992b) Maternal undernutrition during mid-pregnancy in sheep: variable effects on placental growth Journal of Agricultural Science 118 127-132

McFarlane JR, Foulds LM, O'Connor AE, Phllips DJ, Jenkin G, Hearn MT and deKretser DM (1999) Uterine milk protein, a novel activin-binding protein, is present in ovine allantoic fluid Endocrinology $1404745-4752$

McMillen IC, Adams MB, Ross JT, Coulter CL, Simonetta G, Owens JA, Robinson JS and Edwards LJ (2001) Fetal growth restriction: adaptations and consequences Reproduction 122 195-204

McNeill DM, Kelly RW and Williams IH (1997) The partition of nutrients in ewes maintained in a moderate compared with a lean body condition in late pregnancy Australian Journal of Agricultural Research 48 743-752

MAFF (1996) Condition Scoring of Sheep. Action on Animal Welfare 2nd Edition. MAFF Publications, UK
Meat and Livestock Commission (1988) Sheep Improvement Services. Feeding the Ewe 2nd Edn. Meat \& Livestock Commission, UK

Moffatt RJ, Bazer FW, Hansen PJ, Chun PW and Roberts RM (1987) Purification, secretion and immunocytochemical localization of the uterine milk proteins, major progesterone-induced proteins in uterine secretions of the sheep Biology of Reproduction 36 419-430

Moser DR, Lowe WL, Dake BL, Booth BA, Boes M, Clemmons DR and Bar RS (1992) Endothelial cells express insulin-like growth factor binding proteins 2 to 6 Molecular Endocrinology 6 1805-1814

O'Mahoney JV and Adams TE (1989) Nucleotide sequence of an insulin-like growth-factor II cDNA Nucleic Acids Research 175392

Osgerby JC, Gadd TS and Wathes DC (1999a) The effect of maternal nutrition, body condition and genotype on insulin-like growth factorII (IGF-II) in the ovine placenta Growth Hormone \& IGF Research 9187 (Abstract)

Osgerby JC, Reynolds TS and Wathes DC (1999b) The effect of maternal diet and body condition score at mating on placental and fetal growth in the highland (Welsh Mountain) and lowland (Dorset) ewe Journal of Reproduction and Fertility Abstract Series 2386

Osgerby JC, Wathes DC, Howard D and Gadd TS (2002) The effect of maternal undernutrition on ovine fetal growth Journal of Endocrinology 173 131-141

Osgerby JC, Gadd TS and Wathes DC (2003) The effects of maternal nutrition and body condition on placental and fetal growth in the ewe Placenta 24 236-247

Perry IV, Beevers DG, Whincup PH and Bareford D (1995) Predictors of ratio of placental weight to fetal weight in multiethnic community British Medical Journal 310 436-439

Rasby RJ, Wettemann RP, Geisert RD, Rice LE and Wallace CR (1990) Nutrition, body condition and reproduction in beef cows: fetal and placental development, and estrogens and progesterone in plasma Journal of Animal Science 68 4267-4276

Reynolds TS, Stevenson KR and Wathes DC (1997) Pregnancy-specific alterations in the expression of the insulin-like growth factor system during early placental development in the ewe Endocrinology 138 886897

Rhind SM, Rae MT and Brooks AN (2001) Effects of nutrition and environmental factors on the fetal programming of the reproductive axis Reproduction 122 205-214

Schubring C, Kiess W, Englaro P, Rascher W, Dotsch J, Hanitsch S, Attanasio A and Blum WF (1997) Levels of leptin in maternal serum, amniotic fluid, and arterial and venous cord blood: relation to neonatal and placental weight Journal of Clinical Endocrinology and Metabolism 821480 1483

Skopets B and Hansen PJ (1993) Identification of the predominant proteins in uterine fluids of unilaterally pregnant ewes that inhibit lymphocyte proliferation Biology of Reproduction 49 997-1007

Snijders SE, Dillon PG, O'Callaghan D and Boland MP (2000) Effect of genetic merit, milk yield, body condition and lactation number on in vitro oocyte development in dairy cows Theriogenology 53981 989

Spratt SK, Tatsuna GP and Sommer A (1991) Cloning and characterisation of bovine insulin-like growth factor binding protein-3 (bIGFBP-3) Biochemical and Biophysical Research Communications 1771025 1033

Stewart MD, Johnson GA, Gray CA, Burghardt RC, Schuler LA, Joyce MM, Bazer FW and Spencer TE (2000) Prolactin receptor and uterine milk protein expression in the ovine endometrium during the estrous cycle and pregnancy Biology of Reproduction 62 1779-1789

Thomas L, Wallace JM, Aitkin RP, Mercer JG, Trayburn P and Hoggard N (2001) Circulating leptin during ovine pregnancy in relation to maternal nutrition, body composition and pregnancy outcome Journal of Endocrinology 169 465-476

Vernon RG, Clegg RA and Flint DJ (1981) Metabolism of sheep adipose tissue during pregnancy and lactation Biochemistry Journal 200307 314

Wallace LR (1948) The growth of lambs before and after birth in relation to the level of nutrition Journal of Agricultural Science 38 95-153 
Wallace JM, Da Silva P, Aitken RP and Cruickshank MA (1997) Maternal endocrine status in relation to pregnancy outcome in rapidly growing adolescent sheep Journal of Endocrinology 155 359-368

Wallace JM, Bourke DA, Aitken RP and Cruickshank MA (1999) Switching maternal dietary intake at the end of the first trimester has profound effects on placental development and fetal growth in adolescent ewes carrying singleton fetuses Biology of Reproduction 61 101-110

Wallace J, Bourke D, Da Silva P and Aitken R (2001) Nutrient partitioning during adolescent pregnancy Reproduction 122 347-357

Walton A and Hammond J (1938) The maternal effects of growth and conformation in Shire horse-Shetland pony crosses Proceedings of the Royal Society Series B 125 311-335

Wathes DC, Reynolds TS, Robinson RS and Stevenson KR (1998) Role of insulin-like growth factor system in uterine function and placental development in ruminants Journal of Dairy Science 81 1778-1789
Watkins ML and Botto LD (2001) Maternal prepregnancy weight and congenital heart defects in offspring Epidemiology 12 439-446

Werner W, Riekmann P, Rey HG, Wielinger H, Kahle K, Weiss L, Klarwein $\mathbf{M}$ and Wieland $\mathbf{O}$ (1971) A new chromogen for the enzymatic blood glucose determination with GOD-POD Quaderni Sclavo di Diagnostica Clinica e di Laboratorio 7 232-242

Wetterau LA, Moore MG, Lee K-W, Shim ML and Cohen P (1999) Novel aspects of the insulin-like growth factor binding proteins Molecular Genetics and Metabolism 68 161-181

Resubmitted manuscript received 29 January 2003.

Accepted 7 February 2003. 